\title{
Budget Potential of the Region: Attributive Features and Methods of Assessment
}

\author{
Submitted 05/02/19, 1st revision 13/03/19, 2nd revision 17/04/19, accepted 05/06/19
}

\author{
L.L. Igonina ${ }^{1}$, V.V. Vikharev ${ }^{2}$, S.V. Shurygin ${ }^{3}$, D.V. Yaroshenko ${ }^{4}$
}

\begin{abstract}
:
Purpose: The purpose of the article is to clarify the attributive features of budget potential of the region and to develop a method for its assessment, which allows to reflect conditions and prospects of development of regional economics and can provide practical support to financial authorities of state bodies.

Design/Methodology/Approach: In conditions of systemic transformation of the public sector, the problem of efficient diagnostics of budgetary capacity becomes one of the keys in financial science and practice that determines the significance of development of scientific approaches. Findings: In connection with the urgency of the problem of development of budget potential of the regions, determining prospects of growth of regional budget profit and improvement of financial independence of regions, the article on the basis of determining qualitative and quantitative characteristics of budget potential of the region offers the authors ' method of its assessment, which can be used to substantiate real income opportunities of the subject.

Practical implications: The proposed methods, which take into account structuring budget potential of the region, is based on the use of the main financial indicators that reflect general trends and prospects of the regional economics, and provide more accurate determination of income opportunities of the subject of the Russian Federation

Originality / Value. Assessment of projected budget potential will determine income potential of regions in the process of budget planning. This indicator is an information basis for preparation of budget forecasts and an indicator of effectiveness of budget policy of the region.
\end{abstract}

Keywords: Budget potential, region, financial security, evaluation methods.

JEL Codes: H2O, H27, H 60, H68.

Paper Type: Research article in Special Issue dedicated to Russian Economy.

Section 7: Economic Development.

\footnotetext{
${ }^{I}$ D. Sc. In Economics, Professor of the Department of Economics and Finance of Krasnodar branch of Financial University under the Government of the Russian Federation, LLIgonina@fa.ru

${ }^{2}$ Lecturer at the Department of Marketing and Business Communication of Kuban State Technological University.

${ }^{3}$ Post-graduate of the Department of Economic Analysis, Statistics and Finance of the Faculty of Economics of the Kuban State University, -Shurygin.Stanislav@mail.ru

${ }^{4}$ Lecture at the Department of Economics and Finance of Krasnodar branch of Financial University under the Government of the Russian Federation, DVYaroshenko@fa.ru
} 


\section{Introduction}

The implementation of the key purpose of the Russian Federation budget policy, which is to ensure sustainable economic dynamics and to expand potential for balanced development of the country, involves the search for ways of increasing income of budgets of all levels and formation of effective budgetary mechanisms to stimulate investment and economic activity. In this regard, budget potential of Russian regions, its assessment and development of prospect get very important scientific and practical significance. In conditions of system transformation of the public sector, aimed at improving financial security of territories and the quality of life of the population, the problem of efficient diagnostics of budgetary potential of subjects of the Russian Federation becomes one of the main problems in financial science and practice that determines importance of development of scientific approaches to its solution. The object of this article is budgetary potential of the region.

\section{Budget Potential of the Region}

In scientific investigations, the concept of budget potential of the region has a variety of interpretations, which leads to relevant differences in assessment of its scale, structural characteristics, development stratagems. Budgetary potential of the region is considered as:

- potential possibility for financing public goods and services from the budget, based on assessment of total budget resources for financial support of tasks aimed at increasing the level of budgetary provision (Naydenova and Shvetsova, 2013);

- the sum of potentials of all income and expense operating in the region, maximum possible expenses that can be provided by the budget, based on income (Chernova, 2011);

- a set of economic and regulatory conditions that allow to form the optimal amount of income covering normative expenses of the territory, as well as to ensure their targeted and effective use (Yashin and Yashina, 2003);

- the maximum achievable amount of tax income to the budget, which can be obtained within the region in current economic conditions (Barro, 1986; Chernick, 1988);

- potential possibility to accumulate financial resources in the regional budget (Kirillova, 2006), etc.

Analyzing these scientific views and substantiating the author's position, we consider, first of all, semantic meaning of the term «potential». It is interpreted in the dictionaries as sources, opportunities, means, reserves that can be used to solve any problem, achieve a certain goal; opportunities of a person, society, state in a certain area, a set of available means, opportunities in any area (Great Dictionary of Economics, 2004). 
Hence, the budget potential of the region should be considered in connection with possibility of accumulating financial resources into income of regional budget, so it is unlikely to correctly interpret it as maximum possible budget expenditures or the sum of potentials of all incomes and expenditures operating in the region. Of particular importance is the fact that the budget potential is reduced to the tax potential in Russian budget legislation, where it is considered in the context of achieving the level of estimated budget security. However, the concept of budgetary and tax capacities differ both in economic substance and in content. The concept of the «budget potential» is broader than the «tax potential», which is associated with probability of forming the base of only tax income of budget, that is, the part of budget resources.

In this context, the scientific position is more substantiated, according to it the budget potential of the region is interpreted as a set of relevant financial resources accumulated in the budget, that reflects the ability of the regional economics to generate budget revenues in the process of implementing budget functions in accordance with goals and tasks of territorial development. Qualitative characteristics of the budget potential of the region as an economic category contain following essential features:

- probabilistic nature, reflected in the fact that the budget potential is possible, but not actual amount of cash flows into the budget;

- interconnection of the budget potential of the region with the achieved level of development of its economic system;

- dependence of the budget potential on the institutional organization of the economic system of the region. Institutional organization of the economic system is considered as an regularized structural and functional interaction between subjects of this system, forming its elemental structure and hierarchy of structural levels, on the basis of budget rules and regulations, principles of the involvement and use of financial resources, selected forms of budget policy adopted within the current legal framework (Igonina et al., 2017).

Based on this, under the budget potential of the region, we understand the possibility and ability of the regional economic system at this level of its development and institutional organization to generate budget incomes in accordance with goals and tasks of territorial development. In quantitative terms, the budget potential of the region is characterized with the projected amount of financial resources, which, with their maximum involvement and use, can be mobilized for a certain period into budget income within the framework of current legislation, taking into account budget policy. Authors, interpreting the budget potential of the region as the sum of potentials of all incomes and expenditures operating in this region, distinguish in its structure tax incomes of the subjects of the Russian Federation; non-tax incomes of subjects of the Russian Federation and gratuitous incomes, except subventions; the potential of planned expenditures of the subject of the Russian Federation (Zenchenko, 2008). 
Some authors include tax and non-tax incomes (Gladkovskaya, 2018) into the budget potential, others include the tax base, the base of non-tax incomes formation, and possibility of borrowing in the financial markets for budgetary purposes (Aivazov, 2009); third ones - a set of funds raised in the form of taxes, fees, fines and penalties in the region, contributions to territorial extra-budgetary funds, as well as accumulated reserves and funds received as a result of redistribution from budgets and extrabudgetary funds of other levels sufficient for the development of the region on the basis of restructuring and modernization of economics and improving the quality of life in the region (Golodova, 2009).

In our opinion, the budget potential of the region includes possible receipt of tax incomes, non-tax incomes, as well as funds received as a result of redistribution from budgets of other levels of the budget system. In this connection, as a part of budget potential of the region it is possible to consider tax capacity, tax capacity and the budget transfert potential (Yaroshenko, 2017). The transfert or engaged potential is formed at the expense of federal taxes and fees transferred annually into regional budgets according to the Federal law on Federal budget during the next budget year, and also of incomes received by regional budgets in the form of gratuitous receipts from Federal budget (subventions, subsidies, grants). This structuring budget potential of the region, pursuing analytical goals, allows to see its elemental composition, reflecting a particular source of funding and to estimate the share of each of them in the total budget potential (Dombrovsky, 2012).

The Zh.G. Golodova's method involves calculation of the total set of budget coefficients: indicator of covering expenses, concentration of own incomes, security of the population with own incomes, proportion of own incomes of the population to received ones. Depending on values of obtained coefficients, the level of the budget and tax potential of the region (high, above average, average, below average, low) is determined. It is also proposed to calculate an integral indicator characterizing the level of budget and tax potential of regions (Golodova, 2009).

The A.A. Aivazov's method for assessing the budget potential of territories involves calculation of a system of indicators for two analytical blocks, the first of which contains indicators of overall assessment of dynamics and structure of budget coefficients (horizontal, vertical and trend analysis), and the second one contains budget coefficients of autonomy, proportion of financial support received from the Federal budget and own (tax) incomes, the level of budget deficit, budget performance of the region, budget security of the population, budget stability and tax revenues. On the basis of this system of indicators the decision on efficiency of management of budgetary potential is made (Aivazov, 2009).

S.N. Yashin and N.I. Yashinas' method of assessment of the budget potential of the territories, is based on the calculation of four groups of relative indicators based on grouping revenues and expenditures of the budget: repaying obligations with own 
revenues; the structure of revenues; provision of expenses with own revenues; the degree of the tax potential use (Yashin and Yashina, 2003).

Such methods with all their analytical value have at least two drawbacks: 1) coefficients are calculated on the basis of actual data on budget indicators, which reflects retrospective but not probabilistic estimates of budget incomes; 2) it is impossible to determine absolute value of the budget potential of the region.

The accuracy and validity of estimates of the budget potential of the region largely depend on approaches in used methods. Thus, there was an objective need to improve methods for assessing the budget potential of the region.

\section{The Proposed Approach for Assessing Regional Budget Potential}

The choice of approaches in methods is determined, on the one hand, by the specifics of the content interpretation of the budget potential, and, on the other hand, by goals and tasks of assessment. Since we consider the budget potential of the region in quantitative terms as a forecast amount of financial resources, which, with their maximum involvement and use, can be mobilized for a certain period into budget incomes within the framework of the current legislation, taking into account budget policy, and distinguish in its structure tax, non-tax and transfer the budget potentials, value of the total budget potential of the region (BP) can be determined as follows:

$$
\mathrm{BP}=\mathrm{TP}+\mathrm{NtP}+\mathrm{TP}
$$

where NP -value of the tax potential of the region;

$\mathrm{NtP}$ - value of the non-tax potential of the region;

$\mathrm{TP}-$ value of the transfert potential of the region.

All methods of assessment have both advantages and disadvantages, the most accurate results are obtained by integrated methods based on a combination of a number of methods and use of indicators of the total tax base. In this regard, the tax potential should also include:

- unpaid tax arrears and, if it was formed due to violations of tax legislation, but also penalties for their commission. This position should be adjusted for the coefficient of pre-trial settlement of disputes and the coefficient that takes into account percentage of cases successfully challenged by tax authorities in courts;

- tax debts accrued, but not paid due to temporary taxpayers lack of monetary funds, potentially identified amounts of taxes due to evasion of payment, as well as the amount of installments, delays, investment tax credits and other tax benefits provided in the territory of the region.

Methods for assessing the non-tax potential of the region involves calculation of the amount of projected non-tax incomes, which should be adjusted by analogy with the 
tax potential for uncollected, as well as accrued, but not paid debt on non-tax payments. Prospective income of non-tax income, determined by the socio-economic development of the region, the construction of new facilities, the development of some priority for the regions sectors of economics and industries should be included into the calculation of the forecast non-tax potential of the region.

The transfert or raised potential is formed with Federal taxes and fees transferred annually within the process of distribution of the income into regional budgets according to the Federal law on the Federal budget during the next budget year, and also tincome received by regional budgets in the process of interbudget regulation from other budgets of the budgetary system. Thus, the proposed methods for assessing the budget potential of the region can be represented in the form of the following algorithmized model (Figure 1).

Assessment of the projected budget potential will determine the income potential of the regions in the process of budget planning. This indicator is an information basis for preparation of budget forecasts and an indicator of the effectiveness of budget policy of the region. Assessment of proportion of such structural components of the budget potential of the region, both its own potential and transfert one, helps to identify the financial self-sufficiency of territories, forming, in turn, the basis for their sustainable socio-economic development.

Figure 1. Algorithm of the regional budget potential assessment methods

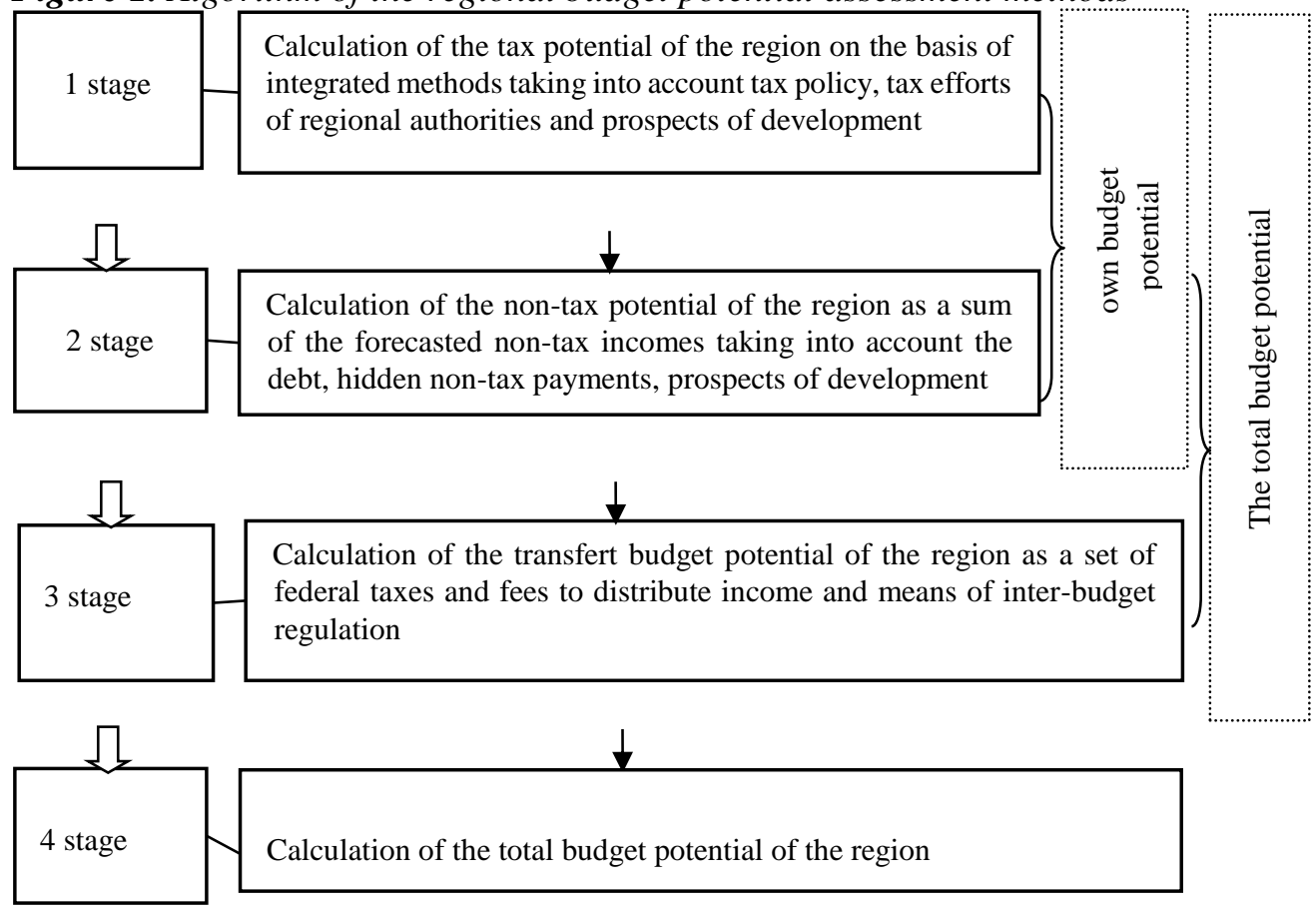




\section{Conclusion}

The discussed method, which takes into account structuring of the budget potential of the region, is based on the use of the main financial indicators that reflect the general trends and prospects of regional economics, and provides more accurate determining income opportunities of the Russian Federation. This technique can be recommended to financial authorities of the Russian Federation for use as analytical support of managerial decisions in order to improve budget process.

\section{References:}

Aivazov, A.A. 2009. Assessment and Directions of Development of the Budget Potential of the Subject of the Russian Federation. Audit and Financial Analysis, 6, 14-16.

Barro, S. 1986. State Fiscal Capacity Measures: A Theoretical Critique. Measuring Fiscal Capacity. Boston: Oelgeschager, Gunn\&Hain Publishers, Inc., 58.

Chernick, H. 1988. Fiscal Capacity in New York: the City versus the Region. National Tax Journal, 3(51), 531-540.

Chernova, S.A. 2011. Prospects for Increasing the Budget Potential of Regions of the Russian Federation. Regional Economics: Theory and Practice, 6(209), 45-50.

Dombrovsky, E.A. Approaches to Srengthening the Base of Regional Budgets. Finance, 7 , 30-33.

Gladkovskaya, E.N. 2018. Tools for Assessing the Budget Potential and Identifying Reserves for Economic Growth in regions of Russian. Fundamental Studies, 10, 31-36.

Golodova, Zh.G. 2009. Assessment of the Budget and Tax Potential of the Region in Conditions of Reforming the System of Inter-budgetary Relations. Finance and Credit, 33-40.

Igonina, L.L., Ashkhotov, V. Yu., Berlin, S.I., Boldyreva, L.V., Bondarenko, V.V., Mamonova, I.V., Kravchenko, N.P, Radchenko, M.V., Roshchektaev, S.A., Solonina, S.V., Tymoshenko, N.V. 2017. The Investment and Financial Potential of Sustainable Socio-economic Development of Krasnodar Region, Moscow, RUSCIENCE, 260.

Isrielian, A.N. 2004. Great Dictionary of Economics. Moscow, Institute of New Economics, 376.

Kirillova, O.S. 2006. Features of Formation and Assessment of the Budget Potential of the region in the context of Municipal Reform in Russia. Finance and Credit, 25(229), 4144.

Naydenova, T.A., Shvetsova, I.N. 2013. Assessment of the Budget Potential of Northern Territories. Finance and Credit, 40(568), 40-51.

Yaroshenko, D.V. 2017. Inter-budgetary Relations in the Russian Federation: Stages of Development, Problems and Ways of Solution (on the example of Krasnodar Region). Economics and Businesses, 10-1(87), 304-307.

Yashin, S.N., Yashina, N.I. 2003. Some Aspects of the Analysis of Budget Potential of Municipalities. Finance and Credit, 5(119), 21-29.

Zenchenko, S.V. 2008. The Budget Potential of the Region and Approaches in Methods to Its Assessment. Regional Problems of transformation in Economics. Makhachkala, Dagestan Scientific Center RAS ISEI, 1(14), 186-198. 